\title{
Roles of dispersal and predation in determining seedling recruitment patterns in a foundational marine angiosperm
}

\author{
Stephen R. Manley ${ }^{1, *}$, Robert J. Orth ${ }^{1}$, Leonardo Ruiz-Montoya ${ }^{2,3}$ \\ ${ }^{1}$ Virginia Institute of Marine Science, College of William \& Mary, Gloucester Point, VA 23062, USA \\ ${ }^{2}$ The University of Western Australia Oceans Institute, Crawley, 6009 Western Australia, Australia \\ ${ }^{3}$ School of Plant Biology, The University of Western Australia, Crawley, 6009 Western Australia, Australia
}

\begin{abstract}
Seed dispersal and seed predation are 2 important processes in the early life history of plants. These mechanisms have been described extensively in terrestrial plants and have resulted in the creation of various models to describe seedling recruitment with increasing distance from the parent plant. However, it is unclear whether theoretical models derived from terrestrial studies apply to marine angiosperms. We performed observational and experimental tests of seed dispersal mechanisms in a marine environment to elucidate patterns of seed dispersal and predation in a foundational marine angiosperm, eelgrass Zostera marina. We also modeled seed dispersal and predation to explore how recruitment varies under different scenarios of predator activity and abundance. We found that seed densities were highest within and adjacent to vegetated areas. Predation pressure was low overall, and there was no significant difference in predation pressure between vegetated and unvegetated areas. Seedling densities were highly correlated with seed densities from the previous year, suggesting that seed predation had a limited impact on population recruitment. These results are consistent with the invariant survival model, which states that seed survivorship has no spatial trend. The theoretical scenarios we generated suggest that a low abundance of highly mobile, generalist predators may explain the patterns observed in our system. Therefore, seedling establishment rates are almost solely attributable and inversely proportional to distance from the parent plant. The results from this study have important implications for the recovery and restoration of these highly threatened coastal ecosystems.
\end{abstract}

KEY WORDS: Seeds $\cdot$ Dispersal $\cdot$ Predation $\cdot$ Seedling recruitment $\cdot$ Zostera marina $\cdot$ JanzenConnell $\cdot$ Hubbell $\cdot$ McCanny

\section{INTRODUCTION}

A number of processes are involved in successful plant recruitment, including seed dispersal, seed and seedling predation, and the availability of refuges (Harper 1977). The interaction between seed dispersal and predation, in particular, has attracted a great deal of attention from terrestrial ecologists (Harper 1977, Howe \& Smallwood 1982, Nathan \& Casagrandi 2004). With respect to dispersal, seeds that disperse farther from the parent plant are less likely to experience strong intraspecific competition, but are more likely to encounter unfavorable conditions for growth and survival (Howe \& Smallwood 1982, Nathan \& Muller-Landau 2000). Alternatively, high densities of seeds close to the seed source may result in density dependent mortality from either predation or intraspecific competition (Janzen 1970, Howe \& Smallwood 1982). Successful seedling recruitment requires balancing this tradeoff between finding the right conditions in which to grow and minimizing predation. 
This interplay between dispersal, competition, predation, and survivorship has led to the development of many theoretical models to explain possible outcomes of seedling recruitment (summarized in Fig. 1). In the first model, maximum seedling recruitment occurs at an intermediate distance from the parent plant, as seeds close to the source experience density dependent predation, while seeds far from the source are less likely to encounter the environmental conditions that favor survival (Janzen 1970, Connell 1971) (Fig. 1a). In the second model, the rate of density dependent predation is not high enough to remove all of the seeds closest to the source, therefore seedling recruitment is highest near the parent, as the seeds are more limited by dispersal than predation (Hubbell 1980) (Fig. 1b). In rare cases, seed survivorship may increase at the same rate as seed dispersal decreases, which results in a net constant seedling establishment rate (Fig. 1c). In some cases, predation is constant across all distances, and seed survivorship either remains constant with increasing distance from the seed source (Fig. 1d), or seed survivorship is highest close to the parent plant, because the seeds are adapted to highly specific microhabitats (McCanny 1985) (Fig. 1e). While many of these recruitment patterns have been shown to occur in terrestrial plants (Nathan \& Casagrandi 2004), these models have not yet been tested in marine plants.

Eelgrass Zostera marina L. is a marine angiosperm found in temperate regions throughout the Northern
Hemisphere that forms dense beds or meadows which act as foundational habitat for a variety of fishes and invertebrates (Beck et al. 2001, Moore \& Short 2006). A number of mechanisms are used by $Z$. marina to disperse seeds over a range of distances, including currents and waves at the sediment surface (effective at a distance of meters), rafting of seeds at the air-water interface via gas bubbles (100s of m), and rafting of whole or partial (spathes or rhipidia) flowering shoots with viable seeds transported by wind and currents also at the air-water interface (100s of km) (Churchill et al. 1985, Harwell \& Orth 2002, Källström et al. 2008, Kendrick et al. 2012, Hosokawa et al. 2015). When released from the parent plant, however, seeds rapidly settle and do not disperse far once on the sediment surface (Orth et al. 1994), where they are quickly buried either by physical processes (i.e. sand movement) or by infaunal organisms (Valdemarsen et al. 2011, Blackburn \& Orth 2013). From release to burial, seeds are subject to predation by different fish and invertebrate species found within and outside established Z. marina beds (Wigand \& Churchill 1988, Fishman \& Orth 1996). However, in our system, predators are considered generalists and consume seeds when available, but do not target seeds directly and thus cannot be considered specialist granivores (Wigand \& Churchill 1988). Interestingly, predation may be responsible for some secondary seed dispersal, as seeds are able to viably pass through the guts of some predators, but it is not well known how frequently this may occur in nature (Sumoski \& Orth 2012). As a consequence of these different mechanisms, the majority of seeds released inside a bed either remain in the parent bed (Hosokawa et al. 2015) or travel short distances (m to $10 \mathrm{~s}$ of $\mathrm{m}$ ) from the source (Churchill et al. 1985, Ruckelshaus 1996), and are subsequently subjected to different sources of mortality.

A recent study using data from an annual, long-term aerial survey of $Z$. marina distribution and abundance across the entire Chesapeake Bay found that a majority of new growth (hypothesized to be primarily from seedlings) occurred within $90 \mathrm{~m}$ from the edge of established $Z$. marina beds (Orth et al. 2013, D. J. Wilcox et al. unpubl. data). While vegetative growth may also have contributed to bed expansion, the average rhizome elonga-
Fig. 1. Population recruitment models using seed dispersal and seed survival to describe seedling establishment: (a) Janzen-Connell, (b) Hubbell, (c) exact compensation, (d) invariant survival, and (e) McCanny. Adapted and reprinted with permission from Nathan \& Casagrandi (2004) 
tion rate for $Z$. marina is approximately $26 \mathrm{~cm} \mathrm{yr}^{-1}$ (Duarte et al. 2006). Therefore, rhizome growth alone could not explain the average annual bed expansion of $10 \mathrm{~s}$ of $\mathrm{m}$ seen in the aerial surveys (D. J. Wilcox et al. unpubl. data). The inferences from aerial maps suggest that seed dispersal and subsequent seedling recruitment in $Z$. marina may decrease with increasing distance from the parent plant, and thus may follow the Hubbell, invariant survival, or McCanny model (Fig. 1b,d,e).

Several studies have examined seed dispersal (Harwell \& Orth 2002, Källström et al. 2008, Hosokawa et al. 2015) and potential predation in Z. marina (Wigand \& Churchill 1988, Fishman \& Orth 1996); however, none have explicitly linked the 2 together in a unified framework. Furthermore, to our knowledge none of the models of terrestrial dispersal and survivorship have been tested in the marine realm. Therefore, the objectives of this study were to determine (1) the patterns of seed dispersal as a function of distance from the seed source in a well-defined Z. marina bed, (2) the predation pressure on seeds within and outside the parent bed, and (3) how the patterns of seed dis- persal and predation relate to observed and simulated seedling recruitment patterns. We conducted observational transects as well as targeted experiments to quantify predation rates on newly dispersed seeds with increasing distance from both the parent plant and the entire $Z$. marina bed. Our work was conducted in a large, dense, continuous but isolated bed that developed from a successful seagrass restoration program in the coastal bays of Virginia, USA (Orth et al. 2012), with the aim of using the identified mechanism to provide scientific guidance for the restoration of this threatened coastal ecosystem (Orth et al. 2006a).

\section{MATERIALS AND METHODS}

\section{Study site}

Seed dispersal and predation experiments were conducted in a Zostera marina meadow in Hog Island Bay, a coastal bay on the Delmarva Peninsula, Virginia, USA (372 $\left.25^{\prime} 2.548^{\prime \prime} \mathrm{N}, 75^{\circ} 43^{\prime} 18.635^{\prime \prime} \mathrm{W}\right)$ (Fig. 2). This

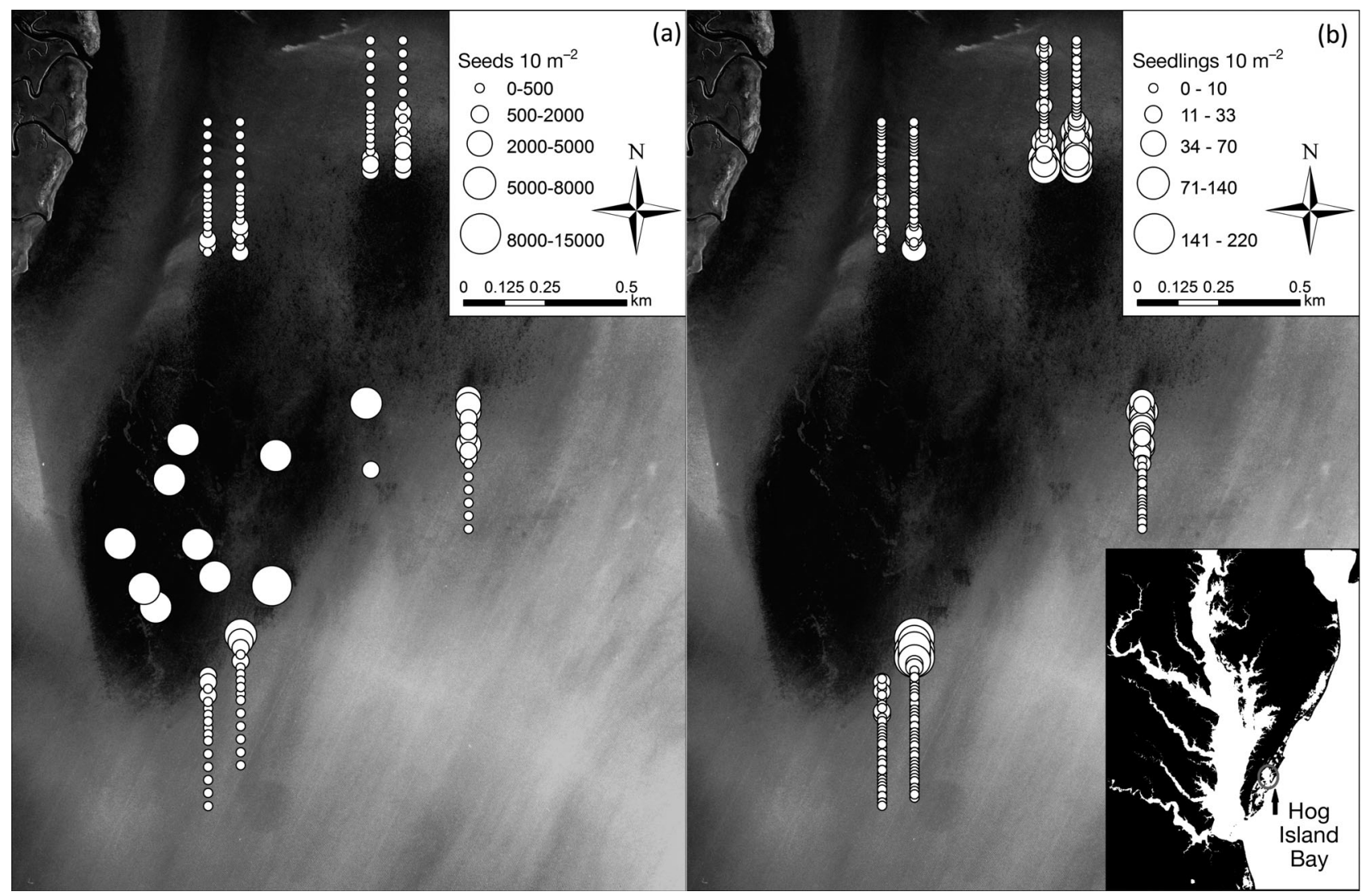

Fig. 2. Aerial photograph taken in June 2012, (1:24 000) of the Zostera marina bed (darker portions of photograph) in Hog Island Bay (Virginia, USA) with (a) the density of seeds $10 \mathrm{~m}^{-2}$ and (b) seedlings $10 \mathrm{~m}^{-2}$ across all locations. Each dot represents a single sample location; dot size indicates the relative proportion of seeds or seedling densities found at that location 
bay had been vegetated prior to the 1930s, when a pandemic die-off resulted in the extirpation of $Z$. marina in this region until 2006, at which point a seed-based restoration effort began (McGlathery et. al. 2012, Orth et al. 2012). From these initial seedings, the bed has expanded to cover 183 ha in 2012 (Orth et al. 2013). This bed is relatively isolated from other $Z$. marina meadows in the region; it is approximately $8 \mathrm{~km}$ from the nearest bed, separated by marsh islands and a deep channel (Orth et al. 2012).

Surveys of adults and seedlings as well as the seed dispersal and seed predation experiments described below were conducted along 4 pairs of $400 \mathrm{~m}$ long $\times$ $1 \mathrm{~m}$ wide transects, which originated near the boundaries of the bed. This boundary was determined from aerial photography taken in 2012, and each pair of transects were positioned such that they transitioned from the edge of the meadow into the unvegetated region at approximately the same distance from the pre-determined edge. All transects were established in a north-south direction, as this is the predominant direction of tidal flow in this area of Hog Island Bay (J. Rheuban unpubl. data). Two pairs were located at the north and 2 at the south end of this bed, with $100 \mathrm{~m}$ separating each pair of transects (Fig. 2).

\section{Seed production}

Reproductive potential was estimated in May 2013 by assessing the number of reproductive shoots per area and the number of seeds per reproductive shoot within the bed. A minimum of eight $0.17 \mathrm{~m}^{2}$ cores were haphazardly taken at 20 randomly selected sample locations throughout the bed. The number of vegetative and reproductive shoots were counted in each core. If no reproductive shoots were found after 8 cores were taken, additional cores were taken until at least 2 cores with reproductive shoots were recorded. A minimum of 15 reproductive shoots were collected at each sample location, and the number of seeds spathe $e^{-1}$ and the number of spathes shoot ${ }^{-1}$ were recorded. Seed production at each sample location was calculated from the average number of reproductive shoots $\mathrm{m}^{-2}$, which was normalized according to the amount of surface area sampled, and then multiplied by the number of estimated seeds shoot ${ }^{-1}$.

\section{Seed, seedling and adult distribution}

Seed distribution was assessed both within and outside of the parent bed. Seeds were sampled in
June 2013, immediately following the release and dispersal of all seeds from the parent plants. Of the 20 random sample locations in the interior of the meadow used to determine seed production, 11 were sampled for the presence of dispersed seeds, using sediment cores taken via suction dredge (Orth \& van Montfrans 1987, Fredette et al. 1990). A bar was added near the end of the core to ensure a constant shallow depth, as viable seeds generally do not occur deep in the sediments (Morita et al. 2007, Jarvis \& Moore 2014). A total of 30 random suction cores were taken before the $1 \mathrm{~mm}$ mesh collection bag was emptied, and the contents were treated as a single sample. Two of these pooled samples were taken at each sample location, for a total of 60 cores location $^{-1}$.

The same suction sampling method was used along the previously described transects to assess seed dispersal moving from unvegetated to vegetated areas (Fig. 2). All transects were sampled every $20 \mathrm{~m}$ for the first $200 \mathrm{~m}$, and then every $40 \mathrm{~m}$ for an additional $200 \mathrm{~m}$, for a total of $400 \mathrm{~m} \mathrm{transect}^{-1}$. At each sample location, 30 suction cores were taken per sample perpendicular to each transect, and the 30 cores from each location were treated as a single sample. All samples were sieved and the number of seeds, seed coats, and spathes were recorded in each sample. The seed density survey was completed immediately after seed release, as seeds are typically buried rapidly (Orth et al. 1994).

The number of seedlings and the percent cover of adult plants were surveyed in May 2013 and April 2014. Divers swam along each transect and recorded the total number of seedlings and percent cover of adult plants every $10 \mathrm{~m}$. Extremely poor visibility prevented divers from recording these data from one of the transects; data from that transect was omitted from the subsequent analyses.

\section{Seed predation}

The spatial distribution of seed predation was measured through the use of predation units. Each unit consisted of a small (10 cm long $\times 3 \mathrm{~cm}$ wide) wooden board containing 8 seeds that were secured using insect pins (size 0). The boards were then anchored to the substrate with metal rebar and large staples. The predation units were placed along the same transects used in the previous studies. However, the transects were extended an additional $100 \mathrm{~m}$ into the bed in order to compare the amount of seed predation well inside and outside the $Z$. marina 
meadow. One seed board was placed every $20 \mathrm{~m}$ for the first $300 \mathrm{~m}$, and then every $40 \mathrm{~m}$ for an additional $160 \mathrm{~m}$, for a total of $460 \mathrm{~m}_{\text {transect }}{ }^{-1}$. The units were deployed in August 2013. While this time period is approximately 2 mo after the $Z$. marina seed dispersal event in June, the predator community in these coastal bays is consistent throughout the summer months (R. J. Orth unpubl. data). Preliminary assays of the predation units showed that it was unlikely that seeds would be removed by abiotic processes for up to $1 \mathrm{wk}$ after deployment, but were readily removed by predators. In this study, the units were deployed and collected after a period of only $24 \mathrm{~h}$. As dispersed seeds settle and are buried rapidly (Orth et al. 1994, Blackburn \& Orth 2013), a time period of only $24 \mathrm{~h}$ was considered appropriate. Upon retrieval, the boards were assessed to determine if any pinned seeds were partially or fully eaten.

\section{Statistical analysis}

As the true edge of the $Z$. marina bed varied with each transect, it was necessary to numerically define the edge of the meadow. The percent cover of adult plants recorded in 2013 was used to define the edge of the bed by creating an accumulation curve as one moved towards the bed along the transect. The edge of the bed was defined when the percent cover of adult plants doubled within a $10 \mathrm{~m}$ span. Each transect was then offset according to the location of the edge. All subsequent analyses were performed according to this edge of bed definition and transect offset.

In order to compare the continuous seedling establishment data to the seed dispersal and predation discrete sampling data, it was also necessary to bin all of the data into $40 \mathrm{~m}$ bins; the averages of each distance bin were then compared by distance. The average number of seeds, 2014 seedlings, and the percent of seeds eaten during the predation assays were also compared against each other using these $40 \mathrm{~m}$ bins. Spearman's rank order correlation tests were performed on these comparisons to determine if there was a correlation between seed and seedling densities and seed predation rates.

A spatial autocorrelation test using the Global Moran's I index was used to determine if there was a spatial pattern in the data, as well as determine if there was significant clustering or dispersal of similar values. This test was performed across all transects on the seed dispersal, seed predation, and 2014 seedling establishment data using the ArcGIS v.10.1 spatial statistics toolset. The Euclidean distance coupled with the inverse distance concept was used on all 3 datasets. The threshold distance was the length of the transects $(400 \mathrm{~m}$ for seed dispersal and 2014 seedling recruitment, $500 \mathrm{~m}$ for seed predation). Row standardization was used because data points were already arranged in a pattern along the transects.

\section{Theoretical vs. observed seedling establishment}

To elucidate mechanisms controlling our observed seedling recruitment pattern, theoretical survival and subsequent establishment were predicted using the model of Nathan \& Casagrandi (2004) under a range of predation scenarios. This model creates a dispersal kernel from seed production and uses it as an input for establishment. It also considers natural mortality and density dependent seed mortality by predation as 2 separate terms. Their simplified model is as follows:

$$
\frac{\mathrm{d} S(\rho, t)}{\mathrm{d} t}=\phi(\rho)-\omega[S(\rho, t)]-\eta[S(\rho, t), \rho]
$$

where the density of seeds on the ground $(S)$ at a specific distance $(\rho)$ over time $(t)$ is calculated by subtracting the loss of seeds due to predation $(\eta)$ and to other sources of mortality $(\omega)$ from the dispersal kernel $(\phi)$.

The dispersal kernel is the seed density in relation to the distance ( $\rho$ ) from the source, which is calculated with a negative exponential function using the number of seeds that are produced $(\alpha)$ and the average travel distance of the seeds $(D)$. Seed mortality is governed by the natural mortality rate $(\mu)$, as well as predator activity. Predator activity is the result of the number of predators in the system $(\beta)$, the average distance the predators are located from the seed source $(q)$, the predator searching rate $(a)$, and the handling time of the seeds $\left(T_{\mathrm{h}}\right)$ by predators. The full model can then be written as:

$$
\begin{aligned}
\frac{\mathrm{d} S(\rho, t)}{\mathrm{d} t}= & \frac{2 \alpha}{\pi D^{2}} \exp \left(-\frac{2 \rho}{D}\right)-\mu S(\rho, t)- \\
& \frac{2 \beta}{\pi q^{2}} \exp \left(-\frac{2 \rho}{q}\right) \frac{a S(\rho, t)}{1+a T_{\mathrm{h}} S(\rho, t)}
\end{aligned}
$$

In order to calculate theoretical seed dispersal, seed predation, and seedling establishment curves, we followed Nathan \& Casagrandi's (2004) approach. First, we calculated the seed dispersal curve by applying the natural mortality rate over the dispersal kernel $(\phi / \omega)$. We then set the left side of this equation to zero, to find the corresponding seed density at 
equilibrium. This equilibrium condition describes the density of potential seed recruits over distance $(\bar{S}[\rho])$; i.e. the seedling establishment curve (Nathan \& Casagrandi 2004). To create the seed survival curve $(\bar{P})$, we used the values at equilibrium to determine the number of seeds that survived predation by calculating the proportion of seeds escaping predation at each given distance: $\bar{P}(\rho)=\mu \bar{S}(\rho) / \phi(\rho)$.

Seed input into the system $\left(\alpha=3000\right.$ seeds $\left.\mathrm{m}^{-2}\right)$ was determined from the values found in the seed production survey. Mortality not due to predation $(\mu=$ $0.75)$, the predator searching rate $(a=25)$, and handling time by predators $\left(T_{\mathrm{h}}=0.005\right)$ were estimated based on our understanding of seed dynamics and our personal observations. These values were kept constant through all runs of the model. A sensitivity analysis was performed on the average dispersal distance of the seeds in order to replicate our dispersal kernel. The model used a single source of seeds to produce the dispersal kernel, and therefore the origin was shifted to inside the meadow. An average seed dispersal distance of $130 \mathrm{~m}$ gave us a dispersal kernel that was most similar in shape to the one found in our observations. Therefore, an average dispersal distance of $130 \mathrm{~m}$ was always used as the primary condition in the following scenarios.

Due to the diversity of possible seed predators in the system, we ran the model using different plausible predator scenarios. We ran the model by increasing the average foraging distance of predators (i.e. $q$ ) from 5 to $100000 \mathrm{~m}$, which helped to determine the predation intensity thresholds that would result in different establishment curves. Based on these results, 3 average predator distances were chosen: a short distance from the source $(q=50 \mathrm{~m})$, a distance

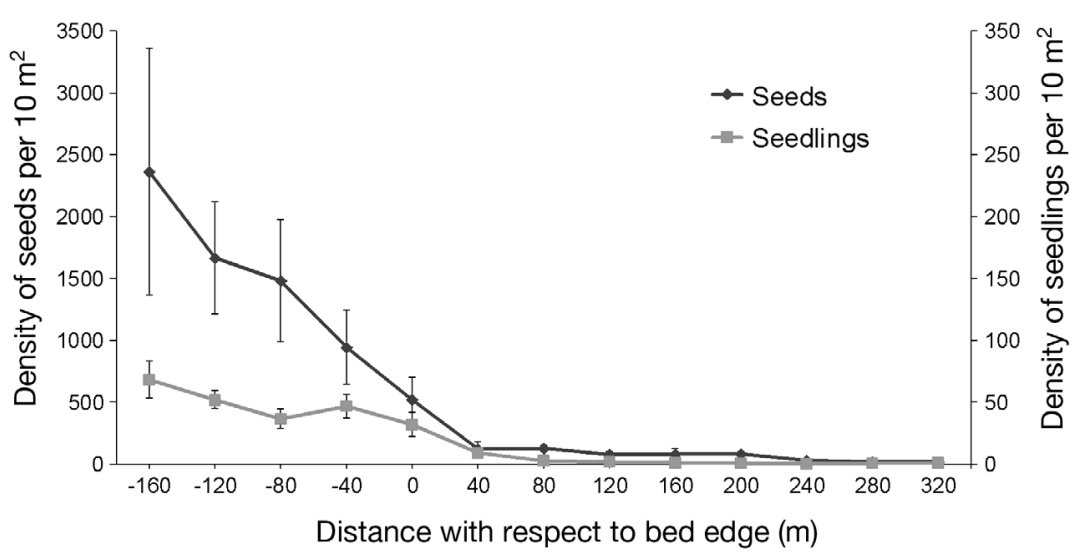

Fig. 3. Average ( \pm SE) density of Zostera marina seeds (left axis) and seedlings (right axis) $10 \mathrm{~m}^{-2}$ across all transects. Data were aligned according to the edge of bed in each transect and grouped into bins of $40 \mathrm{~m}$ equal to the average dispersal distance $(q=130 \mathrm{~m})$, and a much longer distance $(q=500 \mathrm{~m})$. The $500 \mathrm{~m}$ distance was greater than the average seed dispersal distance $(D=130 \mathrm{~m})$ but small enough to affect seedling recruitment patterns. Additionally, $\beta$ was modified to obtain similar ratios of predation pressure per area in high predator population vs. low predator population scenarios. Therefore, a total of 6 models were created, which encompassed predation scenarios from very low predation intensity (small number of predators extended over a large area) to high predation intensity (a large number of predators consolidated in a restricted area close to the source).

\section{RESULTS}

\section{Seed production}

The average $( \pm \mathrm{SE})$ number of seeds produced across all samples was $2796 \pm 259 \mathrm{~m}^{-2}(\mathrm{n}=19)$. The average number of reproductive shoots $\mathrm{m}^{-2}(38 \pm 4)$ was also highly variable. In contrast, the average percent of shoots that were reproductive (14.9 \pm $1.4 \%)$, the number of spathes shoot ${ }^{-1}(10 \pm 0.4)$, and number of seeds within each spathe $(8 \pm 0.1)$ were not as variable.

\section{Seed, seedling, and adult plant distribution}

There was a significant spatial effect on seed and seedling densities $(\mathrm{p}<0.01)$, and sample locations with similar numbers of seeds and seedlings were spatially clustered ( $z=18.45$ and 29.73, respectively). The highest seed and seedling densities were found within or near vegetated areas (Fig. 2). In contrast to seed dispersal and seedling recruitment, there was no spatial autocorrelation in the percent of seeds eaten during the predation assays $(\mathrm{p}=0.31$ ).

Seeds and seedlings were found along the entirety of the transects, but the average density of seeds and seedling recruits decreased with increasing distance from inside the bed (Fig. 3). In addition, when grouped into $40 \mathrm{~m}$ bins, the average density of seeds and average densities of seedlings were significantly and highly correlated with each other $\left(\mathrm{r}_{\mathrm{s}}=0.96, \mathrm{p}<\right.$ 0.01). 


\section{Seed predation}

The average percent of seeds eaten during predation assays showed no spatial trend, either inside or outside the bed, across all $40 \mathrm{~m}$ distance bins (Fig. 4). However, the predation rate inside the bed was more variable. In addition, the predation rate was not significantly correlated with seed densities $\left(r_{s}=0.45, p=\right.$ $0.15)$ or seedling establishment densities $\left(r_{s}=0.51\right.$, $\mathrm{p}=0.09$ ).

\section{Theoretical seedling establishment}

Six likely predator scenarios were generated using our data and the model created by Nathan \& Casagrandi (2004). The first 2 scenarios (Fig. 5a,b) would occur if the average distance between the seed predators and seed source is small $(50 \mathrm{~m})$; under these circumstances, both scenarios show an intermediate seedling recruitment maximum. While the shape of seedling recruitment curve is determined by the average distance between the seed predators and seed source, the magnitude of the seedling establishment maximum is dependent on the number of predators in the system. Therefore, the scenario with smaller numbers of predators (Fig. 5b) allows for a higher seedling recruitment maximum compared to a system with more numerous predators (Fig. 5a).

In the second set of scenarios (Fig. 5c,d), the average distance of predators from the seed source is equal to the average distance of seed dispersal. The predation pattern closely follows the seed density patterns. While areas of high seed density have lower survival rates, the large number of seeds near the source allows many seeds to escape density dependent predation, which results in a seedling establishment maximum near the seed source.

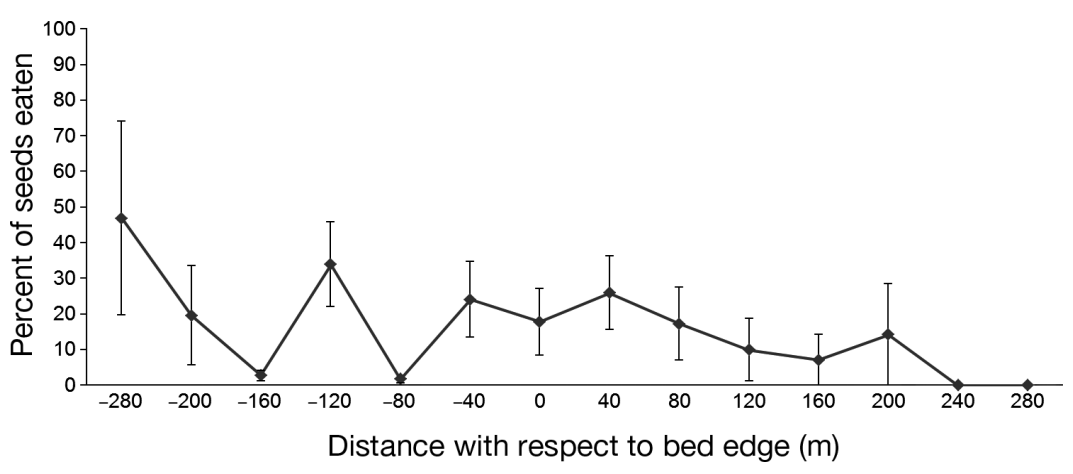

Fig. 4. Average $( \pm \mathrm{SE})$ percent of Zostera marina seeds eaten during predation assays. Data are grouped into $40 \mathrm{~m}$ bins. The $x$-axis shows distance from the bed edge; negative numbers are within the bed
The last 2 models would occur in systems where the average distance between the predators and seed source is greater than the average dispersal distance (Fig. 5e,f). In these models, the seedling establishment is also highest near the seed source and decreases with increasing distance. However, unlike the previous models (Fig. 5c,d), seed survival near the source is higher and increases more gradually with distance from seed source (Fig. 5e,f). The number of predators in the system also appears to have a greater impact on seed survivorship close to the seed source; systems with more predators (Fig. 5e) have significantly lower survival rates near the parent bed compared to systems with fewer predators (Fig. 5f).

\section{DISCUSSION}

Overall, we found that seed density decreased with increasing distance from the parent plant (Fig. 3), and predation was low regardless of distance from bed edge (Fig. 4). These predation patterns are consistent with the invariant survival model (McCanny 1985) (Figs. 1d \& 6), which is often interpreted as a transition between plants that experience density dependent seed predation and those that do not, and can also occur in systems where predators are easily satiated (Nathan \& Casagrandi 2004). This pattern has been shown to occur in a limited number of terrestrial plant species (McCanny 1985, McCanny \& Cavers 1987, Notman et al. 1996), and is thus considered to be the null hypothesis when testing if seed dispersal confers an advantage to the parent plant (Howe \& Smallwood 1982). Therefore, if Zostera marina does in fact follow the invariant survival model, as we highlighted here in our study, we would not expect predation to play a significant role in determining the spatial distribution of seedlings in this system.

While seed predation has figured prominently in several previous studies of marine angiosperms (Fishman \& Orth 1996, Holbrook et al. 2000, Orth et al. 2006b) there are a few potential explanations for the relative unimportance of predation observed in our study. One possibility is that the predators that are present during $Z$. marina reproductive events, in the Hog Island Bay system, such as the blue crab Callinectes sapidus, are omnivorous and forage on any potential food item in both vegetated and unvegetated areas 

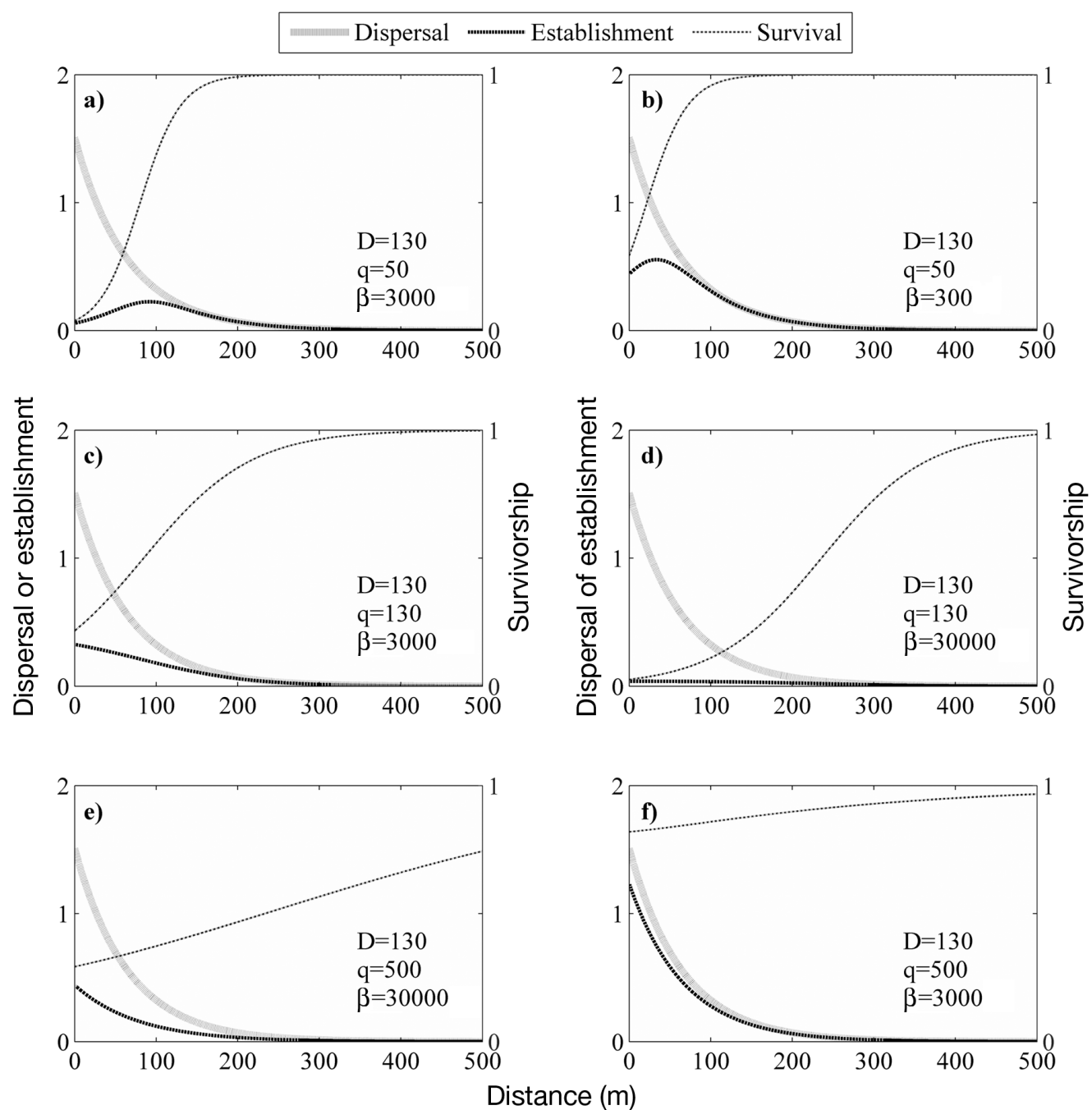

Fig. 5. Scenarios generated using the model first described by Nathan \& Casagrandi (2004). Left axis: Zostera marina seed dispersal and establishment; right axis: seed survivorship. Average seed dispersal $(D$, in $\mathrm{m})$ is held constant while average distance of predators from seed source $(q$, in $\mathrm{m})$ and number of predators in the system $(\beta)$ vary. The scenarios are: (a) short distance between predators and seed source with a high predator density, (b) short distance between predators and seed source with a low predator density, (c) seed dispersal distance and the distance between predators and seed source are equal with a low predator density, (d) seed dispersal distance and the distance between predators and seed source are equal with a high predator density, (e) long distance between predators and seed source with a high predator density, and (f) long distance between predators and seed source with a low predator density

(Heck \& Orth 1980). Therefore, Z. marina seeds may only represent an alternative food source to potential seed predators (Wigand \& Churchill 1988). Conversely, in Australia, Wassenberg \& Hill (1987), Wassenberg (1990) and O'Brien (1994) found seeds of Zostera capricorni to be an important part of the diet of the juvenile brown tiger prawn Penaeus esculentus during periods of seed production. In our study system, the $Z$. marina bed has a high reproductive potential $\left(2796 \pm 259\right.$ seeds $\left.\mathrm{m}^{-2}\right)$ and disperses seeds over a short time span (2 to $3 \mathrm{wk}_{\text {; }}$ Silberhorn et al. 1983, R. J. Orth unpubl. data); a strategy used by numerous plant species to ensure survival of a few seeds (Kelly 1994). Therefore, there is the potential for a mismatch between the timing of seed release and presence of potential predators. Lastly, Z. marina seeds are very small $(1.3 \times 3.0 \mathrm{~mm})$ and may be easily missed in turbid estuarine environments by predators using visual cues, especially if seeds are buried quickly (Orth et al. 1994). All of these possibilities point to an interpretation of the invariant survival model where seeds are not specifically targeted for consumption, and thus overall loss to predation is low.

Other processes besides predation potentially influenced seed survival and seedling establishment patterns in Hog Island Bay during this study. Seed 
and seedling densities were more similar near the bed edge compared to the difference in densities found within vegetated areas (Fig. 3). One hypothesis is that proximity to parent plants may buffer seeds and seedlings from extreme physical disturbance events. In this region, seed and seedling survival is often influenced by sediment disturbances during winter storm events that bury seeds and seedlings either too deeply or are lost when surficial sediments (where seeds and seedlings are located) are eroded (Marion \& Orth 2012). This process can occur within the parent bed as well, but seedlings under the adult canopy may not be able to successfully compete for light during peak spring growth (Olesen 1999). The lack of competition with conspecifics coupled with the reduction in sediment resuspension may partly explain why seeds at the bed edge have a higher rate of survival. Similarly, seeds that remain near the parent bed may benefit from increased organic and nutrient content of the sediments that are often associated with seagrass beds (Short 1987, Hansen et al. 2000, McGlathery et al. 2012). However, areas that have very high sediment organic content could also be detrimental to seeds and seedling establishment (Wicks et al. 2009).

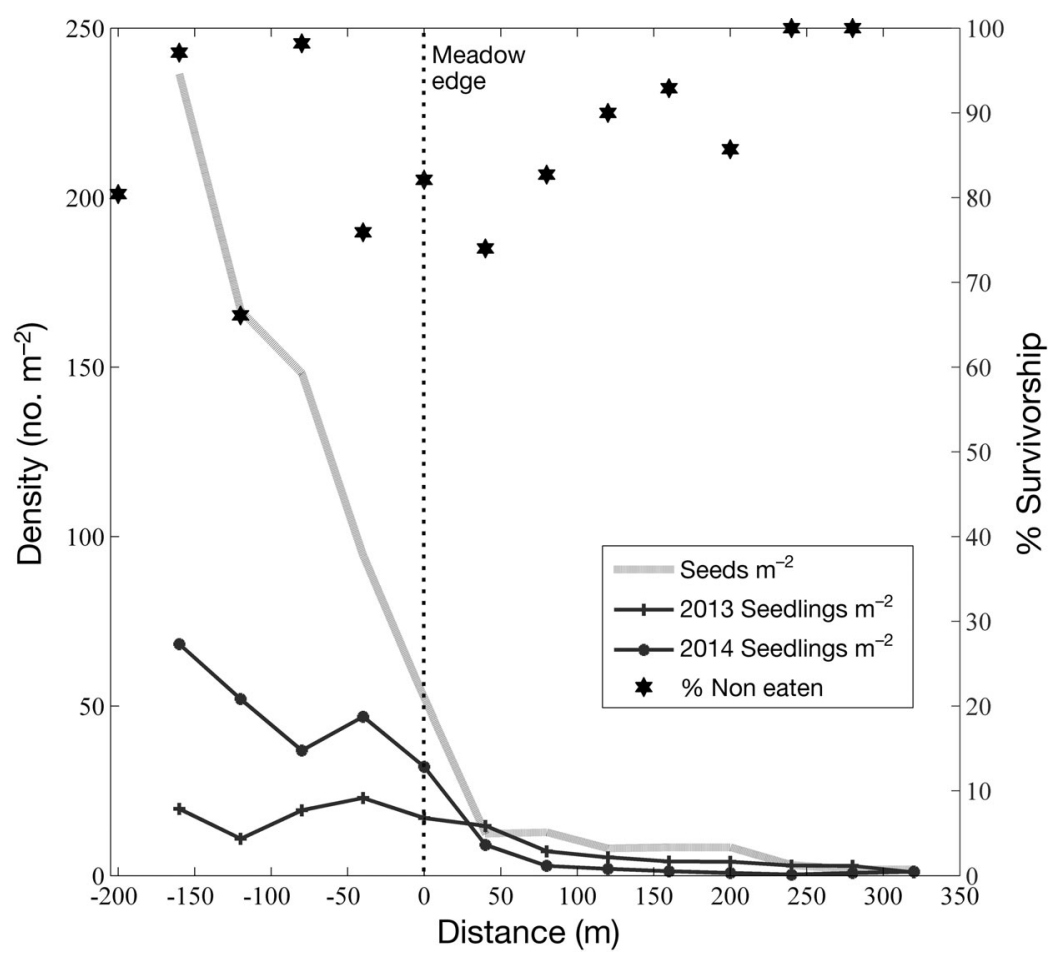

Fig. 6. All data compiled into a single model. Left axis: Zostera marina seed densities from 2013 and seedling densities from 2013 and 2014; right axis: seed escape from predation. Vertical dotted line: edge of the bed. All data are grouped into the $40 \mathrm{~m}$ bins
Another explanation for why seed and seedling densities were more similar near the bed edge compared to the difference in densities found within vegetated areas may be a result of bioturbation processes by infauna. Infauna have been shown to bury seeds rapidly, which is advantageous to seeds as it minimizes predation from visual predators, but also keeps seeds from secondarily dispersing to less preferred habitats (Blackburn \& Orth 2013). However, infauna can occasionally bury seeds to depths that prevent successful germination and establishment (Valdemarsen et al. 2011). Infauna are generally more abundant in densely vegetated areas (Orth 1977), which could result in a higher proportion of deeply buried seeds in the interior areas of the bed and not along the bed edge.

The theoretical scenarios developed in this study suggest that predator activity and population size could have an impact on the $Z$. marina recruitment strategy. In the first 2 scenarios, we modeled the effects of potential seed predators that are likely to remain inside or near the meadow edge where seed abundance is high (Fig. 5a,b). This would create a seedling establishment maximum at an intermediate distance from the seed source, similar to the JanzenConnell hypothesis (Fig. 1a). In the second set of scenarios (Fig. 5c,d), the seed predation pressure is less concentrated near the bed edge, but would become more density dependent, resulting in a lower survival near the edge. However, the highest seedling establishment would still occur closest to the seed source, where the highest seed densities are found. The patterns observed in Hog Island Bay (Fig. 6) are most similar to the final 2 scenarios, which model the effects of highly mobile or generalist predators (Fig. 5e,f). Seed survival is generally higher, and increases more gradually with increasing distance. In addition, the scenario with the smaller predator population (Fig. 5f) appears most similar to the patterns observed in our system (Fig. 6), while the scenario with a larger predator population (Fig. 5e) appears to be more similar to the Hubbell model (Fig. 1b).

The results we observed in our system may have been due to the relatively low abundance of potential seed predators (such as C. sapidus) in 2013. 
The fauna that inhabit mid-Atlantic coastal and estuarine $Z$. marina beds are known to be very dynamic, with high intra- and inter-annual turnover in species composition (Douglass et al. 2010, Sobocinski et al. 2013). In fact, continued monitoring of the $Z$. marina beds in the coastal bays in 2014 revealed much higher abundances of this potential seed predator (R. J. Orth unpubl. data). Thus, the invariant survival model may not hold in years with high predator recruitment. Substantial alterations to local faunal assemblages as the result of habitat loss and fragmentation, invasion, and-particularly in marine communities - overfishing, may cause the patterns seen in either the invariant survival or Hubbell model to become more common over time as potential predators are lost or gained through removal of top predators' trophic cascades (Jackson et al. 2001, Duffy 2006).

As all submersed plant species use different strategies to disperse propagules, the shape of their population recruitment curves, as we have demonstrated here for one species, will require empirical data for establishment rates in relation to the parent bed as well as the vulnerability of seeds and seedlings to predators. For example, Posidonia australis has buoyant fruits that float long distances with seed dehiscense rates within 24 to $72 \mathrm{~h}$ after fruit release of the parent plant, sinking rapidly to the sediment surface (Ruiz-Montoya et al. 2012). However, seed predation rates are extremely low in unvegetated sand compared to inside $P$. australis meadows (Orth et al. 2003, 2006b), suggesting that the invariant model may also apply in this system. Similarly, Thalassia testudinum has buoyant fruits that disperse at the air-water surface (Kaldy \& Dunton 1999) and when seeds are released, they are very susceptible to predation by ubiquitous predators (Darnell \& Dunton 2015). Koch et al. (2010) found that 2 freshwater plants, Potamogeton perfoliatus and Stuckenia pectinata, and one euryhaline species, Ruppia maritima, have negatively buoyant seeds that have limited secondary dispersal from abiotic processes, similar to $Z$. marina seeds. However, some of these species, such as $R$. maritima, may rely on predators such as waterfowl to disperse seeds over long distances (Figuerola et al. 2002). In order to determine which model best describes the population recruitment patterns in $T$. testudinum, $P$. perfoliatus, $S$. pectinate, and $R$. maritima, a greater understanding of seed losses in relation to the parent bed is required.

Our data on seedling recruitment patterns not only have important implications for seagrass recolonization, but also in designing seagrass restoration pro- jects. As seagrasses are also clonal plants and spread laterally via rhizome elongation, many projects account for spread via vegetative propagation (Leschen et al. 2009), but do not take into account subsequent seed dispersal characteristics to enhance the spread of planted plots. Rhizome elongation rates depend on individual species and range from $\mathrm{mm}$ to $\mathrm{m} \mathrm{yr}^{-1}$ (Duarte et al. 2006). However, seed dispersal distances can be $\mathrm{m}$ to $\mathrm{km} \mathrm{yr}^{-1}$ (Kendrick et al. 2012). The average rhizome elongation rate for $Z$. marina is approximately $26 \mathrm{~cm} \mathrm{yr}^{-1}$ (Duarte et al. 2006) while seed dispersal distances depend on how seeds are dispersed, but ranges from $\mathrm{cm}$ to $\mathrm{km}$ (Orth et al. 1994, Harwell \& Orth 2002, Kendrick et al. 2012). Thus, a better understanding of seed dispersal characteristics and dispersal distances as well as predator patterns can help to inform the spatial arrangement and size of individual plots to maximize spread and filling in between plots.

Our data on seed dispersal distances from an established bed offers additional evidence that the rapid success of the large-scale, seed-based Z. marina restoration in Virginia was in part due to the restoration design. Seeds were planted in forty-two 0.4 ha plots in 2001 and 2002, many of which were placed $100 \mathrm{~m}$ from each other (Orth et al. 2012). By 2010, areas between these plots had completely filled in with $Z$. marina. Without seeds, rhizome elongation alone would have taken over a century to infill these plots, yet recovery occurred in less than a decade. Previous studies have looked at how restoration design could affect seed production, and found that site selection and local environmental conditions have the greatest impact on seed production (Harwell \& Rhode 2007). The data from this study and the success of the largescale seed-based $Z$. marina restoration suggest that local conditions as well as restoration design may have an effect on seed dispersal and seedling recruitment from a restored $Z$. marina bed. For example, an area may be restored more rapidly if several small restoration plots are spread over a large area rather than if a single large plot is used to restore a large area. A restoration design with several small plots would take advantage of the fact that recruitment is highest near parent plants regardless of the distance from the bed center, increasing the amount of adultadjacent area versus a single large bed. This design allows for the gaps between the plots to be rapidly filled in through seed dispersal and subsequent seedling recruitment. A similar pattern has been found in the natural expansion of $T$. testudinum in Laguna Madre, Texas (Kaldy \& Dunton 1999), which was thought to occur through a 'leap-frog' mechanism 
whereby small patches of new recruits established outside the parent bed, and vegetative growth filled in the gap between the new recruits and parent bed (Quammen \& Onuf 1993, Kaldy \& Dunton 1999). Our data, showing seed abundances from the Hog Island Bay bed occurring predominantly within $200 \mathrm{~m}$ of the edge, offer direct evidence that a similar mechanism may be found in this system.

\section{CONCLUSIONS}

We found that seed dispersal, not predation, was the predominant driver of seedling distribution and survival in a temperate Zostera marina bed. This population recruitment strategy is most likely the result of the combination of a relative lack of predators that forage specifically for seeds (Orth et al. 2003), compared to the terrestrial systems in which these models were developed, and the high reproductive potential of $Z$. marina. The absence of density dependent seed predation in this species, coupled with short distance dispersal characteristics that retain many seeds near the parent plant, may explain its successful restoration (Orth et al. 2012), indicating that sexual reproduction in $Z$. marina allows this species to quickly rebound from disturbances and recolonize unvegetated areas as long as a seed source is present.

Acknowledgements. We thank S. Marion, A. Johnson, E. Schmitt, S. Sumoski, and C. Holbert for help collecting data, D. Wilcox and G. Kendrick for help with data analysis, L. Jackson for guidance with the seed predation boards, J. Rheuban for providing tidal flow data, and finally, S.R.M's thesis committee, J. Lefcheck, and 2 anonymous reviewers for invaluable comments on the manuscript. This work was funded by the Virginia Institute of Marine Science and Virginia's Recreational Fishing License Fund. This paper is Contribution No. 3481 of the Virginia Institute of Marine Science, College of William \& Mary.

\section{LITERATURE CITED}

Beck MW, Heck KL, Able KW, Childers DL and others (2001) The identification, conservation, and management of estuarine and marine nurseries for fish and invertebrates. Bioscience 51:633-641

Blackburn NJ, Orth RJ (2013) Seed burial in eelgrass Zostera marina: the role of infauna. Mar Ecol Prog Ser 474:135-145

Churchill AC, Nieves G, Brenowitz AH (1985) Flotation and dispersal of eelgrass seeds by gas bubbles. Estuaries 8: 352-354

Connell JH (1971) On the role of natural enemies in preventing competitive exclusion in some marine animals and in rain forest trees. In: den Boer PJ, Gradwell GR (eds)
Dynamics of populations. Centre for Agricultural Publication and Documentation, Wageningen, p 298-312

- Darnell KM, Dunton KH (2015) Consumption of turtle grass seeds and seedlings by crabs in the western Gulf of Mexico. Mar Ecol Prog Ser 520:153-163

Douglass JG, France KE, Richardson P, Duffy JE (2010) Seasonal and interannual change in a Chesapeake Bay eelgrass community: insights into biotic and abiotic control of community structure. Limnol Oceanogr 55:1499-1520

Duarte CM, Fourqurean JW, Krause-Jensen D, Olesen B (2006) Dynamics of seagrass stability and change. In: Larkum AWD, Orth RJ, Duarte CM (eds) Seagrasses: biology, ecology and conservation. Springer, Dordrecht, p 271-294

Duffy JE (2006) Biodiversity and the functioning of seagrass ecosystems. Mar Ecol Prog Ser 311:233-250

Figuerola JA, Green J, Santamaría L (2002) Comparative dispersal effectiveness of wigeongrass seeds by waterfowl wintering in south-west Spain: quantitative and qualitative aspects. J Ecol 90:989-1001

> Fishman JR, Orth RJ (1996) Effects of predation on Zostera marina L. seed abundance. J Exp Mar Biol Ecol 198:11-26

> Fredette TJ, Diaz RJ, van Montfrans J, Orth RJ (1990) Secondary production within a seagrass bed (Zostera marina and Ruppia maritima) in lower Chesapeake Bay. Estuaries 13:431-440

Hansen JC, Udy JW, Perry CJ, Dennison WC, Lomstein BA (2000) Effects of the seagrass Zostera capricorni on sediment microbial processes. Mar Ecol Prog Ser 199:83-96

Harper JL (1977) Population biology of plants. Academic Press, London

Harwell MC, Orth RJ (2002) Long-distance dispersal potential in a marine macrophyte. Ecology 83:3319-3330

> Harwell MC, Rhode JM (2007) Effects of edge/interior and patch structure on reproduction in Zostera marina L. in Chesapeake Bay, USA. Aquat Bot 87:147-154

> Heck KL Jr, Orth RJ (1980) Structural components of eelgrass (Zostera marina) meadows in the lower Chesapeake Bay-decapod Crustacea. Estuaries 3:289-295

Holbrook S, Reed DC, Hansen K, Blanchette CA (2000) Spatial and temporal patterns of predation on seeds of the surfgrass Phyllospadix torreyi. Mar Biol 136:739-747

Hosokawa S, Nakaoka M, Miyoshi E, Kuwae T (2015) Seed dispersal in the seagrass Zostera marina is mostly within the parent bed in a protected bay. Mar Ecol Prog Ser 523: 41-56

Howe HF, Smallwood J (1982) Ecology of seed dispersal. Annu Rev Ecol Syst 13:201-228

> Hubbell SP (1980) Seed predation and the coexistence of tree species in tropical forests. Oikos 35:214-229

> Jackson JB, Kirby MX, Berger WH, Bjorndal KA and others (2001) Historical overfishing and the recent collapse of coastal ecosystems. Science 293:629-637

> Janzen DH (1970) Herbivores and the number of tree species in tropical forests. Am Nat 104:501-528

Jarvis JC, Moore KA (2014) Effects of seed source, sediment type, and burial depth on mixed-annual and perennial Zostera marina L. seed germination and seedling establishment. Estuaries Coasts 459:1-15

Kaldy JE, Dunton KH (1999) Ontogenetic photosynthetic changes, dispersal and survival of Thalassia testudinum (turtle grass) seedlings in a sub-tropical lagoon. J Exp Biol 240:193-212

Källström B, Nyqvist A, Åberg P, Bodin M, André C (2008) Seed rafting as a dispersal strategy for eelgrass (Zostera marina). Aquat Bot 88:148-153 
Kelly D (1994) The evolutionary ecology of mast seeding. Trends Ecol Evol 9:465-470

Kendrick GA, Waycott M, Carruthers TJB, Cambridge ML and others (2012) The central role of dispersal in the maintenance and persistence of seagrass populations. Bioscience 62:56-65

Koch EW, Ailstock MS, Booth DM, Shafer DJ, Magoun AD (2010) The role of currents and waves in the dispersal of submersed angiosperm seeds and seedlings. Res Econ 18:584-595

Leschen A, Kessler R, Estrella B (2009) Eelgrass restoration used as construction impact mitigation in Boston Harbor, Massachusetts. Technical Report TR-37, Massachusetts Division of Marine Fisheries, Boston, MA

> Marion SR, Orth RJ (2012) Seedling establishment in eelgrass: seed burial effects on winter losses of developing seedlings. Mar Ecol Prog Ser 448:197-207

McCanny SJ (1985) Alternatives in parent-offspring relationships in plants. Oikos 45:148-149

$>$ McCanny SJ, Cavers PB (1987) The escape hypothesis: a test involving a temperate, annual grass. Oikos 49:67-76

> McGlathery KJ, Reynolds LK, Cole LW, Orth RJ, Marion SR, Schwarzschild A (2012) Recovery trajectories during state change from bare sediment to eelgrass dominance. Mar Ecol Prog Ser 448:209-221

Moore KA, Short FT (2006) Zostera: biology, ecology, and management. In: Larkum AWD, Orth RJ, Duarte CM (eds) Seagrasses: biology, ecology and conservation. Springer, Dordrecht, p 361-386

Morita T, Okumura H, Abe M, Kurashima A, Maegawa M (2007) Density and distribution of seeds in bottom sediments in Zostera marina beds in Ago Bay, central Japan. Aquat Bot 87:38-42

- Nathan R, Casagrandi R (2004) A simple mechanistic model of seed dispersal, predation and plant establishment: Janzen-Connell and beyond. J Ecol 92: 733-746

Nathan R, Muller-Landau HC (2000) Spatial patterns of seed dispersal, their determinants and consequences for recruitment. Trends Ecol Evol 15:278-285

> Notman E, Gorchov DL, Cornejo F (1996) Effect of distance, aggregation, and habitat on levels of seed predation for two mammal-dispersed neotropical rain forest tree species. Oecologia 106:221-227

O'Brien CJ (1994) Ontogenetic changes in the diet of juvenile brown tiger prawns Penaeus esculentus. Mar Ecol Prog Ser 112:195-200

> Olesen B (1999) Reproduction in Danish eelgrass (Zostera marina L.) stands: size-dependence and biomass partitioning. Aquat Bot 65:209-219

Orth RJ (1977) The importance of sediment stability in seagrass communities. In: Coull BC (ed) Ecology of marine benthos. University of South Carolina Press, Columbia, SC, p 281-300

- Orth RJ, van Montfrans J (1987) Utilization of a seagrass meadow and tidal marsh creek by blue crabs Callinectes sapidus. 2. Seasonal and annual variations in abundance with emphasis on post-settlement juveniles. Mar Ecol Prog Ser 41:283-294

Orth RJ, Luckenbach M, Moore KA (1994) Seed dispersal in

Editorial responsibility: Kenneth Heck,

Dauphin Island, Alabama, USA a marine macrophyte: implications for colonization and restoration. Ecology 75:1927-1939

- Orth RJ, Fishman JR, Harwell MC, Marion SR (2003) Seeddensity effects on germination and initial seedling establishment in eelgrass Zostera marina in the Chesapeake Bay region. Mar Ecol Prog Ser 250:71-79

Orth RJ, Carruthers TJB, Dennison WC, Duarte CM and others (2006a) A global crisis for seagrass ecosystems. Bioscience 56:987-996

> Orth RJ, Kendrick GA, Marion SR (2006b) Predation on Posidonia australis seeds in seagrass habitats of Rottnest Island, Western Australia: patterns and predators. Mar Ecol Prog Ser 313:105-114

> Orth RJ, Moore KA, Marion SR, Wilcox DJ, Parrish DB (2012) Seed addition facilitates eelgrass recovery in a coastal bay system. Mar Ecol Prog Ser 448:177-195

Orth RJ, Wilcox DJ, Whiting JR, Nagey L, Kenne AK, Smith E (2013) Distribution of submerged aquatic vegetation in Chesapeake and Coastal Bays, 2012. Virginia Institute of Marine Science Special Scientific Report No. 155. Final report to the Environmental Protection Agency, Washington, DC

> Quammen ML, Onuf CP (1993) Laguna Madre: seagrass changes continue decades after salinity reduction. Estuaries 16:302-310

Ruckelshaus MH (1996) Estimation of genetic neighborhood parameters from pollen and seed dispersal in the marine angiosperm Zostera marina L. Evolution 50:856-864

Ruiz-Montoya LR, Lowe J, Van Niel KP, Kendrick GA (2012) The role of hydrodynamics on seed dispersal in seagrasses. Limnol Oceanogr 57:1257-1265

Short FT (1987) Effects of sediment nutrients on seagrasses: literature review and mesocosm experiment. Aquat Bot 27:41-57

Silberhorn GM, Orth RJ, Moore KA (1983) Anthesis and seed production in Zostera marina L. (eelgrass) from the Chesapeake Bay. Aquat Bot 15:133-144

Sobocinski KL, Orth RJ, Fabrizio MC, Latour RJ (2013) Historical comparison of fish community structure in lower Chesapeake Bay seagrass habitats. Estuaries Coasts 36: 775-794

Sumoski SE, Orth RJ (2012) Biotic dispersal in eelgrass Zostera marina. Mar Ecol Prog Ser 471:1-10

Valdemarsen T, Wendelboe K, Egelund JT, Kristensen E, Flindt MR (2011) Burial of seeds and seedlings by the lugworm Arenicola marina hampers eelgrass (Zostera marina) recovery. J Exp Biol 410:45-52

> Wassenberg TJ (1990) Seasonal feeding on Zostera capricorni seeds by juvenile Penaeus esculentus (Crustacea: Decapoda) in Moreton Bay, Queensland. Aust J Mar Freshw Res 41:301-310

Wassenberg TJ, Hill BJ (1987) Natural diet of tiger prawns Penaeus esculentus and Penaeus semisulcatus. Aust J Mar Freshw Res 13:85-92

- Wicks EC, Koch EW, O'Neil JM, Elliston K (2009) Effects of sediment organic content and hydrodynamic conditions on the growth and distribution of Zostera marina. Mar Ecol Prog Ser 378:71-80

- Wigand C, Churchill AC (1988) Laboratory studies on eelgrass seed and seedling predation. Estuaries 11:180-183

Submitted: December 17, 2014; Accepted: May 19, 2015

Proofs received from author(s): July 17, 2015 